\title{
8. Progress and Decay in the 21st Century
}

\author{
The Postmodern Uncanny Child in The Others (Alejandro
} Amenábar, 2001)

\begin{abstract}
Chapter Eight outlines the specific ways that transnational uncanny child characters trouble entrenched cultural investments in teleological progress via the theoretical framework of Dylan Trigg's 'aesthetics of decay'. The chapter argues that these child figures unravel the process of growing up and transform it into one of 'becoming', a Deleuzian term that designates a process of change that resists teleological goals and end-states. The analysis in this chapter centres on one of the most influential and critically successful films of the early 200os, THE OTHERs (Alejandro Amenábar, 2001), which thematizes the decline of traditional, modernist conceptions of the child.
\end{abstract}

Keywords: Aesthetics of decay, Progress, The Others, Decline, Postmodernity, Modernity, Uncanny child

As has been explored throughout this book in the context of specific cultural conditions, the millennial turn represented a global pause in the unquestioned progression of history, forcing a reconsideration of the mechanics of sociohistorical time. This is crystallized in globally pervasive anxieties about institutional collapse, such as the $\mathrm{Y}_{2} \mathrm{~K}$ Bug: a particularly potent incarnation of millennial disquiet that characteristically hinged on the fear that technological malfunction would unsettle coherent temporality on a mass scale. As Joseph Natoli puts it:

Is the new millennium a fresh start, a fresh winding of the clock? Or, is it more what we fear it is: a painful reminder of what might have been, of a

Balanzategui, J., The Uncanny Child in Transnational Cinema: Ghosts of Futurity at the Turn of the Twenty-First Century, Amsterdam University Press, 2018.

DOI: 10.5117/9789462986510/CHo8 
time when future time was hopeful and not already wearied, redundant, bearing more of what has already been packaged than what is new and inconceivable? $(1998,13)$

In transnational remakes and coproductions, the child becomes implicated in this anxious uncertainty as to what the new millennium represents, as the previously naturalized relationship between past, present, and future starts to unravel and specific historical narratives are displaced. Baudrillard characterizes millenarism as a challenge to established conceptions of historical time, for, unlike historicism, 'which continually shifts the stakes to a hypothetical end, [millenarism] is characterized by a fatal exigency, a fatal strategy of time which wants to shoot straight ahead to a point beyond the end' $(1994,8)$. For Baudrillard, the turn of the millennium represents the final breaking apart of linear time, a mode of temporality that has buttressed teleological conceptions of cultural progression since the Enlightenment: the millennial turn is thus 'our non-Euclidean fin de siècle' in which 'the future no longer exists' $(1994,11)$.

This shift in conceptualizations of futurity at the turn of the 21st century obviously has strong implications for the child - the 'emblem of futurity's unquestioned value' (Edelman, 2004, 3) - and indeed, concerns about the child's ideological function in the new millennium suffused the beginning of the 21st century. All of the films discussed in this book so far express such anxieties, deploying the uncanny child trope to consider specific cultural and historical implications of millennial shift. Yet, by stripping back cultural specificity and self-consciously considering the form and function of the uncanny child, transnational remakes and coproductions instead consider in more general terms what the uncanny child figure suggests about the shifting ideological status of childhood at the beginning of the 21st century, and, more precisely, what the postmodern disintegration of linear historicity and progress means for childhood's conceptual apparatus.

\section{Childhood and the Decline of Progress and Futurity}

As Jack Zipes elucidates, cultural critics of childhood became fixated with what the symbolic contortions associated with millennial transition meant for children in the early 200os, wondering:

Are they being made more violent, sexual, and sick by the images of brutality, sex and horror on the big and little screens of television, the Internet, and the cinema? Are the new digital technologies transforming 
literacies and the way children read so that they are no longer reflective and capable of sustained reading? How does advertising affect the brains of children from infancy through their teens? What are they actually imbibing? What are they learning if they are learning? What do they do with that experience? $(2009,2)$

Similarly, Paula Fass questions, 'I wonder [...] whether the particular, romantic, Western vision of the sentimental child may not have outgrown its usefulness, to become so cliché ridden that it can no longer cover the needs of children' $(2007,255)$. These scholars are concerned with how concepts of the child were reinscribed by the cultural and technological shifts heralded by the beginning of the 21st century, and latent in their commentary is the understanding that unquestioned investment in progress and futurity is no longer a viable narrative to enforce upon the child's growth.

Echoing Baudrillard, Zygmunt Bauman suggests - in a quote positioned at the opening of Zipes's own consideration of the status of childhood in postmodern culture - that "Progress", once the most extreme manifestation of radical optimism and a promise of universally shared and lasting happiness, has moved all the way to the opposite, dystopian and fatalistic pole of anticipation' $(2007,10)$. Bauman points to a change in the way progress is conceptualized with the beginning of the 21st century, as looking to the future became an exercise no longer associated with positive change. As Svetlana Boym puts it, at the close of the 2oth century, 'optimistic belief in the future became outmoded' $(2007,7)$. With the arrival of the long-awaited 'future' represented by the 21st century came only more uncertainty and violence, as signified most potently by the 11 September 2001 terrorist attacks on the United States and subsequent Iraq war. Phillip Hammond expounds: 'in the absence of any confident vision of the future, $9 / 11$ further intensified an already heightened sense of vulnerability and fear. In Baudrillard's terms, the attack could indeed be said to have revealed the "internal fragility" of the system' $(2007,4)$.

In this context, the alignment of growing up with social progress that anchors modernist understandings of childhood becomes an ominous pairing fraught with anxious anticipation. As Jenks points out, throughout modernity:

the metaphoricity through which the discourse of childhood speaks is predicated on the absent presence of a desired tomorrow, with 'growth,' 'maturation' and 'development' writ large at the level of individual socialization. [...] by way of children, we have, through modernity, dreamt of futures, and in so doing we have both justified and sought justification 
for modernity's expansionist urges in the post-Darwinian conflation of growth and progress. $\left(2005,105^{-106}\right)$

However, with the decline of modernity throughout the second half of the 2oth century and the emergence of the uncertainties of the distinctly post- or, to use Bauman's terms, 'liquid' modern 21st century, 'group affiliations' and aspirations no longer have such an influence over individual identities (Jenks, 2005, 107), and, as a result 'the new experience of history, at both the individual level and the level of institutions, is one of discontinuity rather than of continuity' $(2005,107)$.

As we have seen in Chapter Seven, the uncanny children in transnational remakes and coproductions embody troubling detachments from cultural belonging. At the same time, however, this development represents a compelling movement away from previous models of childhood, in which the child's growing up is made to serve adult-centred narratives of personal, historical, and national advancement. Despite the anxieties of childhood scholars such as Zipes and Fass, this postmodern shift in our understandings of progress unsettles the previously unquestioned binding of childhood to the needs of adult politics in potentially generative ways. Threatening and often monstrous in their affront to traditional modes of national identification and progress, the uncanny children of early 21st century transnational horror nevertheless represent a productive symbolic reconfiguration of childhood, playing out in dramatic fashion the obsolescence of the innocent, romantic, or to use Fass's term, 'sentimental' child.

\section{The Uncanny Child and the Aesthetics of Decay}

The specific manner by which the transnational uncanny child deconstructs the traditional, teleological conception of progress is to expose progress's entwinement with decline. In so doing, the child figure envisages a cultural moment in which all that was once familiar - all the quotidian elements of the society that was in the 2oth century - suddenly become unfamiliar in the 21st, so that temporal progression itself becomes a vehicle for the uncanny. This process can be elucidated via Dylan Trigg's 'aesthetics of decay': an aesthetic study of 'the ontological value of [...] decay' (2006, xxix) partly inspired by Walter Benjamin's own study of decaying ruins. Throghout his book The Aesthetics of Decay, Trigg critiques what he calls a 'fixed image' of progress, suggesting that decline and its outward manifestation, decay, can reveal to us an altered perception of time passing outside of progressivist narratives of historical, economic, and technological advance. 
As intimated above, the sense that society had approached the end of historical development as we know it suffused the late 1990s and early 2000s, a phenomenon which Baudrillard characterizes thus:

now we encounter strange, altered, random, and chaotic events that Historical Reason no longer recognizes as its own. Even if, by analogy with past events, we think we recognize them, they no longer have the same meaning. The same incidents (wars, ethnic conflicts, nationalisms, the unification of Europe) do not have the same meaning when they arise as part of a history in progress as they do in the context of a history in decline. Now, we find ourselves in a vanishing history, and that is why they appear as ghost events to us. $(2008,161)$

Expressing a similar sentiment, Jörn Rüsen explicitly links the 21st century decline of history with globalization and postmodernism:

at the turn of the twenty-first century the term 'history' brings extremely ambivalent associations to mind [...] whether in reference to [...] postmodernism, or to the challenge to Western dominance by decolonization and multiculturalism, 'history' as we know it has been declared to be dead, outdated, overcome, and at its end. (2007, vii)

Anxieties about the decline of history are an extension of postmodern discourse that has circulated throughout the latter half of the 20 th century, cohered in Lyotard's work on the decline of the metanarrative, which famously outlines how 'the grand narrative has lost its credibility, regardless of what mode of unification it uses' $(1983,37)$.

However, the beginning of the 21st century brought with it a renewed fixation with the decline of historical continuity, as incredulity towards the metanarrative became not just a reified component of academic discourse, but a felt condition that suffused global popular culture. As Niles Tomlinson points out, "historically, degeneration is a discourse intimately braided with fin-de-siecle, millennial or end-time anxiety about transformation, revelation, and apocalypse' $(2010,185)$. While fixations with decline and apocalypse usually manifest as pessimistic anxieties about the fall of society - as in Baudrillard's work - the millennial fixation with decline also marks apprehension for the emergence of new symbolic structures. As Lois Zamora elucidates in her examination of the conceptual underpinnings of apocalypse myths, 'apocalypse projects the patterns of creation, growth, decay, renewal, catastrophe onto history, 
encompassing the beginning and the end of time within its vision' (1988, $89)$.

Trigg's aesthetics of decay provide an optique through which to conceptualize this early 21st century entanglement of decay and growth, decline and emergence. While Trigg does not explicitly analyse the millennial turn, his book, published in 2006, offers a rethinking of temporal continuity that can effectively be applied to the tangling of endings and beginnings that characterized the transition into the 21st century, suggesting the generative potential of history's 'decline'. Trigg suggests that what he calls the 'fixed' or 'rational' mode of progress is inevitably bound to the ideological structures of the past, as our visions of futurity are constructed out of epistemological structures with roots in the past, bound together under the umbrella term, 'reason' (what Baudrillard refers to as 'Historical Reason'). Thus, even though rational progress infers a continual process of positive change, the values and conceptual apparatus underlying rational progress are fixed, determined by modernist ideologies of scientific enlightenment, human endeavour, and national histories. As Trigg conceives it, fixed progress is a process of continual deferment in which the present remains incomplete, but is sustained by the promise that this epistemic incompleteness will eventually be filled by an imagined, 'nostalgic' future (a term that exposes how investment in futurity is actually shaped by the past): "The nostalgia for the future informs the endurance of the unfinished present and makes that present bearable. In political terms, the failed promise that the next term of government will bring about improvement relies on the same logic' $(2006,229)$. The cultural logic that sustains our hopes for the future emerges from the rational structures of the past, providing cultures and nations with a sense of historical continuity. Furthermore, through progress, the past is fulfilled with meaning that serves the needs of the present. Trigg's assertion thus accords with Edelman's suggestion that our sociocultural usage of the child to maintain temporal continuity is at its core conservative and stultifying because 'it works to affirm a structure, to authenticate social order, which it then intends to transmit to the future in the form of its inner Child' (Edelman, 2004, 3).

As I have outlined in previous chapters, the child is inevitably bound up with various 'fixed images' of progress. Symbolically embedded in the figure of the child are the incongruent temporal vectors of progress: childhood represents a lost past suffused with adult nostalgia and retrospective longing - and, in fact, childhood only attains such symbolic value through the adult's retrospective view - while the child as social actor represents the vehicle through which we conceptualize and shape the course of futurity. 
The child's temporal function is thus to provide narrative clarity to rational progress, facilitating a sense of intergenerational (or social) and psychic (or personal) development. The child thus embodies a form of temporal continuity that makes meaning of the past and future, while domesticating radical change in the present. As Jenks points out, throughout modernity, the child has functioned as 'a "promise" of unimagined action, but also an extension of our own plans and a hedge against our own action as yet incomplete. Such a commitment has, for several generations, enabled us to indulge in pleasant reveries concerning tomorrow' $(2005,104)$. Thus, the child's temporal function, aligned as it is with a fixed image of progress, is adult-centric, fulfilling the needs of the adult's present: childhood gives meaning to the adult's past, while the child is tasked with realizing a future that emerges from the adult's present and promises to anneal its gaps. As Jenks puts it, 'what could not be achieved today could be set in train for tomorrow' $(2005,107)$ through the child.

Trigg suggests that rational progress comes undone in the decaying ruins of society: formerly quotidian spaces which now exist in a state of disuse and decay, but have not been considered of enough historic value to sanctify and preserve in the form of a monument. As Trigg outlines, 'in the continuity of its disbanding, the ruin rewards us with insight, and so creates a space in which the end of rationality converges. Thinking alongside the ruin means recognizing its ability to evaluate progress' (2006, xvii-xix). In temporal terms, 'these ruins are close enough to the present to mirror an alternative past/present/future. A derelict factory testifies to a failed past but also reminds us that the future may end in ruin' (2006, xxvii). While the preservation of a space or site as a historical monument entails the solidification of a particular narrative of history, the abandoned, decaying spaces of society capture a temporal admixture of past, present, and future not clarified via temporal narratives of advance: a building that was not long previously a component of a city- or townscape - formerly unnoticeable through its unproblematic belonging to the present - is rendered visible through dropping out of use and becoming outmoded. Such structures thus impel us to conceptualize the continual transition of the present into pasts that are not captured within historical narratives. As Trigg explains:

unlike the enforcement of a political agenda through the conservation of the monument, the ruin frees us from an already formed definition of history. [...] The false arrangement of the past, whereby the surplus remains are discarded, presenting history as an ordered, self-contained, and rationalistic project, is overruled by the emergence of the past in the ruin, as fragmented and incomplete. $(2006,238)$ 
These decaying spaces resist the conventional sense that the past 'makes sense' to us in light of the progress that has been made and continues to drive the present, and that, in a similar manner, in the future, the dreams of the present will be fulfilled due to the onwards march of progress. Instead, the ruin incarnates 'the preservation of a past, manifest not by the fulfilment of that past, but through its decay' (my emphasis, Trigg, 2012, 269).

In transnational horror films, the uncanny child, her degraded technologies, and the forgotten, decaying spaces in which she lurks are united in energizing this liminal moment of transition, in which progress appears to be moving towards its apparent opposite: decay. As Trigg elucidates, 'the ruin is in a process of constant becoming-toward. It moves' (emphasis in original, 2006, 236) - the ruin is compelling in that it is 'becoming-toward' dissolution, as futurity becomes not a fantastical distant horizon, but just as palpable within this (soon-to-be)non-structure as the recent past, as is represented by the decaying building's former function as a factory, a hospital, or school. Thus, like the uncanny child, the ruin perceptually draws the temporal polarities of past and future together, resulting in an eerily unmediated sense of progress stripped of its fixity and optimism. Hereby, in their entwinement, the uncanny child and her decaying, unhomely spaces capture the temporal quality at the heart of the uncanny: as Anthony Vidler explains, for Freud the unheimlich 'was more than a simple sense of not belonging; it was the fundamental propensity of the familiar to turn on its owners, suddenly to become defamiliarized, derealized, as if in a dream' $(1992,7)$.

As will be illuminated via my analysis of THE OTHERs in this chapter - and THE RING in the next - in transnational uncanny child films of the early 21st century, the eerie sense that homely space has turned on its (adult) owners is entwined with the realization that the child has dissociated herself from the adult-centric mode of rational progress, to expose its uncanny underside: decline. This process entails a symbolic defamiliarization of all that was taken for granted throughout the 2oth century - its technologies, spaces, and modernist conceptual apparatus - a self-conscious shift in historical and temporal consciousness. Furthermore, because these children are exposed to be at a point of flux between growth and decay, life and death, they conflate and confuse beginnings and endings in a way that expresses the upheavals of millennial shift.

A recurring motif of these films is the decaying body of a child alongside a building or technology in the throes of abandonment and/or decay, both of which are rendered aesthetically and narratively powerful via the very process of decline in which they are caught. Progress is realized not as a 
continual advancement forward - a growing 'up' - but an unsettlingly liminal space of transition between states, with no triumphant end state. As a result, these films impel us to experience temporal progression as the eerie splitting of the present into both lost pasts and futures, in a self-aware stripping away of progressive historical metanarratives. No longer interacting with contained national identities and histories, these uncanny children thus instead engage with the very epistemologies of progress and change, and in so doing conceptually transform the process of 'growing up' to one of 'becoming', a term ubiquitous throughout the work of Deleuze. Deleuze uses this term in a diverse range of contexts across his oeuvre, but it is essentially a generative process of 'passage, change' (1997a, 17), which he links directly to entrenched notions of history in Negotiations: 'History amounts only to the set of preconditions, however recent, that one leaves behind in order to "become," that is, to create something new' (1997b, 171). As Cliff Stagoll explains, 'becoming is the pure movement evident in changes between particular events. [...] Rather than a product, final or interim, becoming is the very dynamism of change, situated between heterogenous terms and tending towards no particular goal or end-state' $(2013,26)$. The becomings of the uncanny children in these films - most commonly typified as their becoming-corpse and becoming-ghost - harness this 'non-linear dynamic process of change' (Marcel Swiboda, 2013, 30) to express the ontological contortions of technological transition and history in flux. In various ways, the children resist simple representation as either a ghost or a living child, a dichotomy that structures almost all of the films discussed in previous chapters. In THE OTHERS and THE RING, we are instead privy to the child's processes of becoming between these states.

Emma Uprichard points out that children constantly mediate a tension between being and becoming: they exist as social actors, or 'beings', in the present, yet are also continually 'becoming' adults, as their status as adults-in-the-making continually looms over their conceptualization (2008, 303-313). The transnational uncanny child subverts this processual becoming, in which the process of change according to which the child is defined points towards a fulfilled end point in the future: namely, adulthood. Being caught in the throes of death and decay, these children will never fulfil futurity's promise of becoming an adult - thus, nor do they promise to anneal the gaps in the adult's present - but instead linger at a point of continual transition to a corpse, dust, a ghost, a memory. They thus derail the quotidian and adult-centric mode of becoming to which Uprichard refers, and transform it into a becoming stripped of a vision of futurity set in place by adults of the present. As a result, the transnational uncanny child disassembles 
the ontology of rational progress. This process represents a self-reflexive extension of all the films previously analysed in this book, in which the uncanny child challenges specific modes of personal and national progress.

\section{'Sooner or later she'll see them. Then everything will be different': The Decline of Modernity in THE OTHERS}

THE OTHERS is one of the most successful horror films of the 21st century, and received significant attention at major film award ceremonies, a rare display of critical appreciation for a horror film. In addition to winning major awards at Spain's Goyas and other prominent ceremonies such as the London Film Critics and Saturn Awards, the film was nominated for major awards at both the British Film Academy Awards and the Golden Globes. ${ }^{1}$ The lasting cultural impact of THE OTHERs is signalled by the extent to which it has been referenced, parodied, and otherwise circulated throughout popular culture: it has been spoofed in SCARY Movie 3 (David Zucker, 2003) and SpANish Movie (Javier Ruiz Caldera, 2009); inspired a Hindi remake, WHO ARE WE? (Ravi Sharma Shanka, 2004); and was a major reference in THE Simpsons Halloween episode, 'Treehouse of Horror XXV' (Matthew Faughnan, 2014). The film coheres many of the refrains of the uncanny child cycle into a compelling reflection on how our entwined understandings of childhood, progress, and historical time underwent a profound shift in the early 21st century.

THE OTHERS is suffused with the aesthetics of spatiotemporal dislocation and unhomeliness, a self-conscious refraction of the film's distinctly liminal, transnational production context - as I outlined in the previous chapter, the film is a Spanish-American coproduction set on the Isle of Jersey, an island off the coast of France that is a self-governing possession of the British Crown. The entire film takes place within a moment of transition from homely space into unhomeliness, a point of spatial flux the film aligns with the temporal shift from present into pastness. The children, Anne and Nicholas, embody this eerie vision of progress founded not on advancement and futurity, but on becoming and decline. As Trigg explains, 'our ability to be aroused

1 The film won eight Goyas, including Best Film and Best Director; was nominated for six Saturn awards, winning Best Horror Film, Best Actress (Nicole Kidman), and Best Supporting Actress (Fionnula Flanagan); won the London Film Critics Award for Best Actress of the Year (Nicole Kidman); was nominated for a Golden Globe Award for Best Actress in a Drama (Nicole Kidman); and received a BAFTA nomination for Best Original Screenplay and won the award for Best Actress in a Leading Role (Nicole Kidman). 
by the ruin' - and thus to experience progress's form undomesticated by teleological trajectories of history - is 'dependent upon our sensitivity to the polarized tension between the homely and the unhomely' $(2006,138)$. In The OTHERs, this continual tension also underlies the sense that the rational structures to which protagonist Grace clings in order to make sense of her existence are captured in a state of dissolution: not only does the house turn on its owner, but so too do all the ideological assumptions for which it stands, as both are simultaneously exposed to be in the process of fading into the past. ${ }^{2}$ The family is thus haunted by the future, not the past. These themes are all tied to the fact that Grace and her children are ghosts, but are not yet aware of their spectral status. Unbeknownst to them (and the audience, until the final ten minutes, if the twist ending works as intended), they have already dropped out of the onwards march of historical progression, and are spectres of a past that is being replaced with a new present, as represented by the new family who are moving into the house. Grace's children sense these intruders throughout the film and refer to them as 'the others'.

\section{Historical Uncertainty and the Post-WWII Period}

This stripping away of rational progress is emphasized by the setting of the film. As the opening subtitle informs us, the film takes place in 1945, the year WWII ended: a symbolic moment of conceptual transition that represents both the beginning of the modern epoch's decline, and the gradual emergence of postmodernity from modernity's smouldering remnants. As J. T. Fraser suggests '[p] ostmodernism is a post-Second World War phenomenon. It may best be described as a reflection of changes which are so rapid as to make their integration into the recent past and onrushing future impossible' $(1996,5)$. Fraser's expression of a temporality that does not seem to naturally synthesize into historical time suggests why Amenábar (who wrote as well as directed the film) uses the post-WWII period to work through the temporal uncertainty of the early 21st century. The post-WWII period is often positioned as the nebulous beginnings of postmodernity due to a sense that these years saw the beginning of modernity's degeneration. As Rein Staal puts it: 'The aspirations that had inspired the founders of modern thought - the conquest of nature through science, indeed the conquest of human nature through science and the emancipation of power from moral

2 Notably, the house is a grand, late Victorian-era mansion - symbolic of a zenith of the modern period - in actuality, the Palacio de los Hornillos, built in 1904, is in Las Frugas, Cantabria. 
restraint - had been achieved beyond anyone's wildest dreams, and they had turned to ashes before that success could be enjoyed' (2008, 35). THE ОтнЕRs retrospectively confronts the epistemic uncertainty nascent in the post-WWII period, positioning it as a symbolic parallel to the unsettling of historical progression represented by the millennial turn.

Because the film is set in an isolated mansion on the Isle of Jersey - the only setting depicted in the film - the direct and immediate implications of WWII are eerily intangible and distanced, unable to be arranged into historical meaning. That WWII is continually represented as an event that does not 'belong' to the film's characters expresses the film's transnationality: Spain did not participate in WWII, and was officially nonbelligerent. The Channel Islands, of which Jersey is a part, were occupied by the German forces throughout the war, and were liberated on 9 May 1945. Significantly, the film does not provide a date in 1945 for its setting, so the current status of the war and occupation is left unclear. Enhancing this uncertainty, Grace refers to the presence of Germans in vague terms: at first she fears 'the others' haunting the property may be German spies. The lack of a clear chronological relationship to the end of the war and the liberation of the Channel Islands renders the precise political and historical context of the diegesis ungraspable and subversively liminal, as the film resists contextual tethering along a trajectory from war to victory.

Just as the audience is not offered precise historical context, nor do the characters seem to be aware of their grounding in historical time. Early in the film, Grace explains to the housekeepers that her husband, Charles, went to war a year and a half ago, yet she has had no news 'since the war ended'. The children believe their father is still fighting in the war, and their vague awareness of the war's significance is only measured through its scale and distance: 'our father is fighting in a war in France, you know', Anne proclaims, while Nicholas corrects 'It's a World War', to which Anne replies 'I know, but he's in France.' When the children ask their mother about their father, she tells them that he shall return 'when the war's over', contradicting her earlier suggestion that it has already ended. Nicholas replies: 'Why did he go to war? I mean, nobody's done anything bad to us', further reinforcing the family's detachment from their sociopolitical context. Even when Charles mysteriously emerges from the woods surrounding the mansion halfway through the film, both his own status and that of the war remains obscure: as the housekeeper suggests, 'he doesn't really know where he is'. The audience is none the wiser, as it remains unclear whether Charles is a traumatized living man, or a spectre caught forever in the war, having died on the battlefield. He disappears as quickly and inexplicably as 
he reemerges, explaining to Grace that he must return 'to the front', which prompts the following exchange:

Grace: The war's over.

Charles: The war's not over.

Grace: What are you talking about?

Hovering at this point of confusion and disagreement, the dialogue again leaves the temporal stage of the war in doubt, eventually leading Grace to cry out in frustration 'Why did you go to that stupid war that had nothing to do with us?'

The specifics of historical trauma are thus replaced in THE OTHERS with the temporal and ideological uncertainty of a liminal moment between clearly definable historical stages. In turn, the film's unsteady grasp on postwar historical consciousness pointedly marks the beginning of the decline of modern thought. Reflecting this transitory temporal context, the house itself is situated not as a stable site but as transitional space, with many of the myriad rooms depicted with the furniture packed away, covered in sheets, and unused, creating insecurity as to whether these belongings have long been packed up due to disuse, in readiness to move, or have simply never been unpacked. As the plot emphasizes, both of these vectors - imminent unhomeliness and imminent homeliness - are coexistent in this interstitial zone in which modernist discourse has started to unravel: Grace and the children's hold on their home may be coming undone now that they are spectres, but the new family are only just settling in.

\section{Uncanny Childhood and the Decline of Adult Discourse}

Anne and Nicholas are the threads that bind Grace to this isolated space dislocated from cultural belonging and historical trajectories. The children are photosensitive: bright light would cause their skin to blister and rupture, so the house is kept in a state of constant darkness (as is emphasized by the lack of electricity). Because the curtains are constantly pulled closed to protect the children, natural light very rarely enters the house, and, as a result, it is frequently unclear throughout the film as to whether it is night or day. Fog continually obscures the spatial boundaries of the house in exterior shots, whereas shadow and darkness render the internal structure of the house unclear: the walls of rooms and hallways are frequently obscured, as a dull halo of gas lamp light is all that illuminates the characters in the shot. We are thus not offered coherent spatial coordinates with which 
to comprehend the house or the characters' position in space, and it is the children's vaguely defined condition that necessitates this constant shroud of shadow. The children thus unsettle the status of homeliness, as the spatial familiarity, security, and identity that make a house a 'home' are not apparent in this claustrophobic, uneasy space.

In order to deal with this spatiotemporal aimlessness, Grace adheres to artificially constructed rituals that provide her existence with a sense of coherence and direction. When the mysterious new servants arrive (as we later learn, they are in fact ghosts from the Victorian era, having died in 1891), Grace is quick to instruct them of the exact times at which she and the children must have their meals and other facets of their schedule, an insistence on strict timekeeping matched by her precise way of dealing with the vast darkness of the house's rooms and hallways. Grace has keys for every room, and instructs the servants on the rules of locking one room before passing into the next, an orderly spatial traversal which mirrors her insistence on chronological coherence. Grace's adherence to socially constructed rituals is also indicated by her awareness of the weekly visiting schedules of the priest and postman, which constitute her only tenuous connections with the world beyond her property. Grace's devotion to these rituals also represents her only means of maintaining a chronological sense of time within the darkened house. Grace is introduced through her attachment to chronology: the film's opening shot is an extreme close-up of her screaming in horror, but upon checking her watch, she breathes a sigh of relief. Despite Grace's relief when she looks at her watch, from the beginning of the film the temporal structures to which Grace clings have already dissolved. Her relief, after all, is founded on her inability to confront her trauma: she is buoyed by her mistaken belief that she did not actually go through with the act of killing herself and her children.

The children's incitement of a temporally insecure unhome through their 'condition' is entwined with their burgeoning resistance to the ideological structures that their mother holds dear - beliefs aggrandized by Grace's devout Roman Catholicism. ${ }^{3}$ Throughout the film, we witness scenes of Grace teaching her children regimented lessons from the Bible, yet both children later admit to the housekeeper that they do not entirely believe what they have been taught in these lessons. The children are also depicted reading

3 Grace's oppressive Roman Catholicism also vaguely signals the Spanish contexts that echo throughout the film, as this discourse goes hand-in-hand with Franco-era fascism, and is often depicted as such in Spanish film (most infamously in the works of Luis Buñuel, such as VIRIDIANA $[1960])$. 
out lessons about traditional family units, half-heartedly dictating the text from their readers: 'We all live in a house with our families. The family is usually made up of parents, children, and their grandparents. We must be obedient and kind towards other members of our family.' Reflecting Trigg's notion of a fixed image of progress, these lessons perpetuate a conservative, intergenerational model of temporal continuance in which futurity emerges from the structures and institutions of the past, the master figure of which is the nuclear family unit. As Jenks points out, 'the modern family has become the basic unit of social cohesion in advancing capitalism, and though loving and supportive in its self-image it has become the very epitome of the rational enterprise. [...] The modern family enabled the modern State to invest in "futures"' $(2005,105)$. The children's conceptual entwinement with this formally sanctified mode of temporal progression is also signalled by a message written on the blackboard which appears throughout the film: 'Thank God for Their Growth in Faith and Love.'

Yet the children - Anne in particular - continually challenge the structures and assumptions upon which the 'rational enterprise' is founded. Following the mysterious reemergence of their father, the children ask their mother to where one's soul goes when one has died fighting in a war. The following exchange ensues:

Grace: That depends on whether you fought on the side of the goodies or the baddies. Your father, he fought for England on the side of the goodies.

Anne: How do you know who the goodies and the baddies are?

Grace: That's enough questions. Eat your food.

Anne immediately proceeds to bring up the subject of the mysterious 'others' that she has perceived lurking in the house once again - exposing the entwinement of these intruders with the child's resistance to her mother's teachings - but Grace angrily dismisses Anne, insisting that the child be silent, leading Anne to run from the dinner table. As the housekeeper tells the frustrated girl in the adjacent kitchen: 'There are things your mother doesn't want to hear. She only believes in what she was taught. But don't worry, sooner or later, she'll see them. And then everything will be different.'

The child, and the ghosts from the future that she perceives, thus embody a challenge to her mother's belief system: while the child in modern discourse is tasked with continuing the adult's present into futurity, Anne represents the decline of her mother's reality. As Trigg suggests: 
decline is the imminent fall of a narrative already aware of its limitations. Decay is the outward manifestation of decline, which allows subjectivity to recognize itself in that narrative. If not seen as pernicious in their own right, decay and decline are an anathema to the progressive march of reason. $(2006,84)$

Anne's awareness of the limitations of her mother's rigid discourse heralds the imminent collapse of this discourse, and its subsequent transition from present into pastness. In charting Grace's gradual recognition that she and her children are dead, the film entwines Grace's belated recognition of trauma with a realization that all the ideological structures that buttress her identity are collapsing. This is the uncanny point at which she recognizes herself within a narrative of decline, rather than advancement, as crystallized in the realization that 'her' home is in fact no longer 'hers': both her identity and her home are thus caught at a moment of defamiliarization.

This sense of modernity in decline is captured in a recurring motif throughout the film in which Grace enters various rooms of the house and rips the sheets off of the belongings stored inside. In one of the film's key set pieces, Grace searches for the 'intruders' in a room that Anne provocatively labels the 'junk room'. Inside the room is a large assemblage of objects covered in white sheets, and thus unclear in their individual forms and properties. The objects themselves seem like the ghosts haunting the room - a point further suggested by the fact that, moments before this sequence, Anne declares that ghosts 'go around in white sheets'. Grace hears indiscernible whispering, but this eerie murmuring seems to emanate not from spectres, but from the ghostly objects that surround her as she nervously traverses the room. As the whispers crescendo to a pronounced moaning sound, Grace is startled and backs into a set of outstretched hands, before ripping the sheet off in terror to reveal a full-sized Virgin Mary statue. She then proceeds to frantically pull off the sheets covering various other objects in the room, including a coat stand, which teeters frantically with the force of its unveiling, and two mirrors, the second of which Grace nervously stares into. The 'junk' thus represents the source of terror in this scene, rather than any supernatural occurrence.

As Grace looks in the mirror, the camera captures her from behind, before slowly dollying into her reflection to focus on the door that is slowly creaking closed behind her: both Grace and the camera shift focus from her reflection to the events taking place behind her back. Grace's identity is thus decentralized, placed off-centre, and eventually blurred in favour of the activities of the 'ghosts' behind her, who in fact presage Grace's own 
displacement into the past. The objects in the 'junk room' represent the flotsam and jetsam of modern consciousness, caught at a point of decline marked by the post-WWII period. Likewise, the intruders are not actually the film's ghosts: the spectres are Grace herself, her children, and the objects with which she surrounds herself. Near the end of the film, in a scene immediately prior to the grand reveal that Grace and her children are ghosts, Grace is once again seen in the junk room. Yet this time, in her desperate quest to locate the curtains that the 'ghosts' have removed from the windows - which finally serves to bathe the house and its dark corners in light - Grace is seen carelessly pushing, throwing, and smashing the objects that embody her threatened belief system.

\section{The Parallel Perversion of Growing Up and Rational Progress}

In a similar manner to the eerie ghosts of modernity represented by the objects in the junk room, the children embody a point at which development and grow th are revealed to be decline and decay. Initially, Anne and Nicholas appear to be traditional models of pure and innocent childhood, pale blank slates primed to be filled with adult knowledge and to enact its continuity into the future. They thus seem to embody the promise that meaning will soon be restored to their mother's identity, to the film itself, and to this uncanny period of time that is yet to be inscribed with historical meaning: an expectation signalled by the statement 'Thank God for Their Growth in Faith and Love.' Yet it gradually becomes clear that Anne and Nicholas actually herald the outmodedness of their mother's modernist, adult-centric understanding of childhood's function. Rather than ensuring the continuance of Grace's beliefs and genes into the future, the children - particularly Anne - are harbingers for their mother's obsolescence.

Aestheticizing Anne's embodiment of decline is a scene two-thirds into the film, which echoes the earlier sequence in the junk room. In the scene, Anne tries on a dress that her mother has made for her, intended for the child's first communion. Anne's first communion represents another of Grace's religious and temporally bound rituals, which, in this case, serves to mark the holy confirmation, and thus utter enculturation of Anne's identity into her mother's ideologies. Temporally, the communion represents a way for Grace to quantify Anne's growth and consecrate a symbolic transition from irrational infant child into the adult's 'age of reason' - the traditional purpose of the first communion. However, importantly, Anne is already a ghost at this point, exposing the communion's status as an empty ritual seeking to affix temporal and rational coordinates where none exist. Significantly, 
although Anne tries on the dress, following the horrors of this scene, outlined below, the child never actually goes through with the ritual. The sequence represents the film's key horror set piece and has become the most referenced moment of THE OTHERS.

As Anne wears the dress, we see Anne and her mother's reflection in the mirror as they admire her mother's creations - both the child and the dress she wears. Yet, as her mother gently places the veil over the child's face and Anne stands frozen in place, admiring her reflection, her ghostliness - and her similarity to the immobile objects in the junk room - is eerily suggested. When Grace briefly leaves the child alone in the room, the editing becomes uncomfortably disorienting. At first, the child is filmed from behind, her mirror image captured but not her body. When the camera does cut back to the child in real space, the rules of cinematographic continuity are broken as the camera jumps across the 180-degree line, unsettling the audience's grasp of how the child relates to the space. This is followed by a flurry of jump cuts between a full frontal shot of Anne apparently standing before the mirror, a shot of her mirror image (however, the darkness and strangeness of the angles make it difficult to discern which is the real child and which is her mirror image), and a shot from a higher angle depicting Anne standing in an unexpected position in the room. As Nicola Diamond points out, this disorienting series of shots 'happens so fast, taking the viewer by surprise, and this affects the viewer pre-reflectively. The disruption of body identity affects our sense of spatial orientation and renders a state of das Unheimlich that we share for a split second' $(2014,95)$. The sequence creates the fleeting impression that there are multiple Annes in the room, visually expressing the breaking apart of the child's traditional function and her dispersal into decay and pastness, even as her actions speak of growth and futurity - throughout the scene, she is pretending to enact her wedding dance.

When Grace returns to the room, Anne is again captured from behind, singing the same nursery rhyme-esque melody that she has hummed throughout the scene. However, as the camera closes in on the child, now a crumpled figure on the floor playing with a marionette, Grace and the audience become privy to the withered, wrinkled nature of the hand that protrudes from the lacy white sleeve of the gown. Anne's gentle humming enhances the eeriness of the contrast, as childish sweetness is swiftly rendered uncanny. As the camera revolves around the figure's body to capture her frontally, it becomes evident that the face beneath the veil is no longer that of a child, but of an old woman. She continues to speak in Anne's sweet voice, yet moves in unnatural, stilted movements not unlike the puppet with which she plays: a parallel which emphasizes the sense of 
uncanny doubling and becoming-other that permeates this sequence. The scene frighteningly articulates the child's untethering from clearly marked temporal coordinates of growing up - a process which functions in tandem with the film's lack of clearly defined cultural and historical context - as the pure, untarnished body of the child is suddenly imaged in a state of elderly decay, a juxtaposition amplified through the disjuncture between the childish voice and the gnarled face and hands. Exposed in this scene are the true horrors of the child's ghostliness: the child is no longer fixed on a progressive timeline, and instead conflates the usually opposed polarities of growth and decay.

Horrified, Grace desperately grabs at the child's dress, trying literally to unveil Anne as she did the objects in the junk room. When Grace violently removes the veil, her shock is at first registered in her mirror image, before a reverse shot captures both Grace in real space and Anne - once more appearing as a child - standing before her. Grace repeatedly screams 'you're not my daughter!', her abject horror expressing her terrified resistance towards the collapse of her intergenerational continuance. The uncanniness of this sequence is only enhanced by its narrative explanation, revealed later in the film: the child-ghost, depicted at a moment that marks a symbolically significant point in her 'growth', suddenly merges with an elderly medium attempting to make contact with her from the future, a medium that the new occupants have hired to make contact with the ghosts haunting 'their' house. The child's function as vessel for futurity and historical continuity thus unravels, as the child's body becomes synonymous with the 'untimely' quality of the decaying ruin: 'having fallen from (active) time, the ruin becomes disjoined from time. The untimeliness is evident in how past, present, and future conspire to converge in the ruin' (Trigg, 2006, 131).

\section{'We're not dead!': Subverting the Narrative Structure of the Ghost Story}

This disjoining from historical time culminates in the climactic scene, in which Grace and her children realize that they are spectres. Finally confronting the 'intruders', the family come across a husband, wife, and two spiritualists (including the elderly medium who previously possessed Anne) sitting at a large table in the drawing room conducting a séance. At this point, the past and future finally reach a point of collision, which in fact represents a crashing into the diegesis of the film's 'real' present. In some shots, only the family sitting at the table are visible, and the only evidence of Grace and the children's presence is the shuddering of the table and a flurrying of the papers on which the medium is writing. In alternative shots, Grace and 


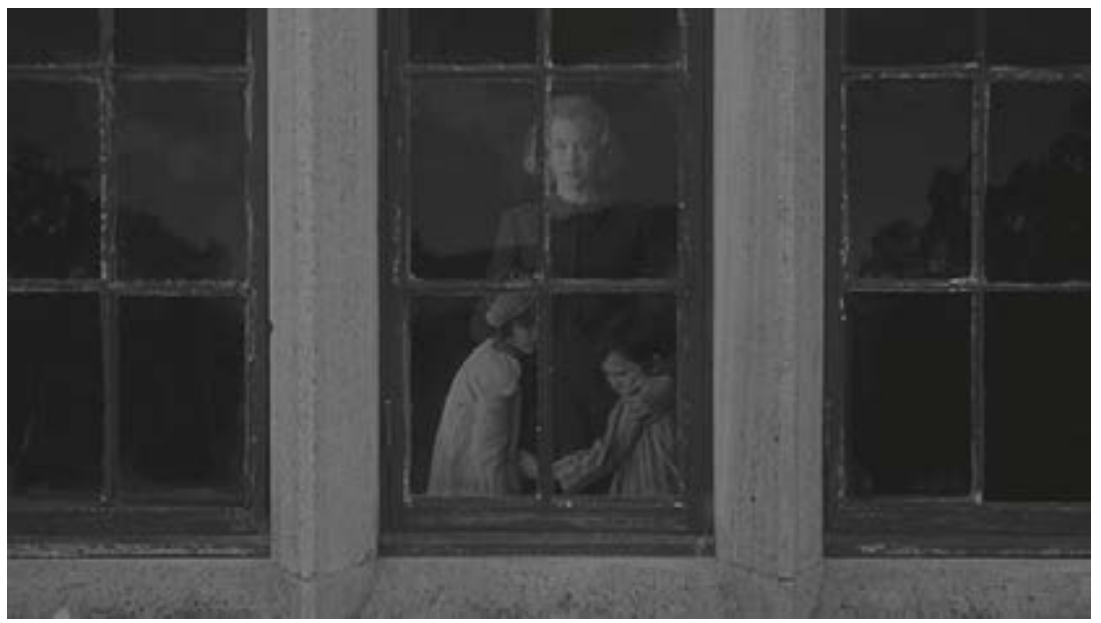

Figure 15. Grace and the children haunt the new occupants in the final image of the family in THE OtHERS.

the children once more appear in the frame, violently shaking the table and moving the papers - desperate acts that only serve to emphasize their lack of visibility in the present. 'We're not dead!' the children and their mother repeatedly cry out: the desperate last cries of a former present, incarnating in traumatic form the moment at which the present diegesis of the film reveals itself to be the past. Grace and the children are becoming-past as a new present takes their place, an image of progress which foregrounds not advancement, but the decline and displacement of the previous mode of being. As her world becomes unhomely, Grace is finally forced to question her beliefs, saying to the children when they ask her about how their (non) existence fits into the dichotomies of heaven, limbo, and hell: 'I'm not even sure if there is a limbo. I'm no wiser than you are.' The adult character no longer has dominion over the children's epistemic reality now that they are untethered from the narratives of intergenerational and historical continuation that the adult had set in place.

The film impels the audience to experience this uncanny defamiliarization of progress by subverting the typical trajectory of the ghost story. In one of the film's final scenes, Grace and her children repeatedly whisper, 'This house is ours.' The whispering accompanies floating shots of the now empty rooms of the house. This is thus an eerie vision of space devoid of its occupants, rendered anonymous for it is no longer semiotically anchored as the characters' home. Exposing their flailing grasp on the space, Grace and her children use the word house in their frantic recitations, emptying the structure of its homeliness in tandem with a montage of deterritorialized, 
floating shots that no longer have a subject on which to focus. This sequence echoes a motif typical to the ghost story, except that now we are haunted not by the reemergence of a past that disturbs the status of the present and the flow of temporal progress - as in all the films previously discussed in this book -, but by the gradual displacement of a past in progress's wake. This is succinctly captured in the final shot of the family, in which we finally see Grace and her children from the living child Victor's point of view: as Victor stares up from the grounds of the mansion, the family appear as eerily transparent, static figures in the top-floor window, who gradually fade away and disappear (Fig. 15). This shot references an image typically featured in the first third of ghost films, as Grace and her two children gaze ominously through the window, watching as the new occupants flee the house that Grace no longer owns, but haunts. This shot underscores the viewer's realization that 'the others' of the title are the characters with which we have identified for the duration of the film, not the 'intruders'. ${ }^{4}$

From this point, the camera pulls away from the house - the grounds now bathed in a bright light that had been elusive for the duration of the film - and follows the car of the living family as they leave the property. Although we are at first given the impression that we, the audience, will follow this car out along the road, and thus rejoin the forward march of historical progress, in fact the camera stops at the gate as the car leaves the grounds. As the car continues beyond the gate and moves out of frame, the final shot lingers on the 'For Sale' sign which hangs on the gate, before fading to black. Instead of releasing us from the displaced past in the final shot, the film thus hovers at the point of becoming spatially represented by the unsold, haunted house, no longer belonging to the dead previous occupants, but yet to be grounded in the present by new owners and colonized with new life and meaning.

4 To be specific, the final shot in THE OTHERs echoes an early scene from The INNOcENTs, in which Miss Giddens wanders the grounds of the mansion before noticing a spectral figure staring down at her from the tower. Similarly, in THE HAUnTING when Eleanor walks around the grounds of the mansion in which she is staying, she constantly senses something looking down at her from the uppermost window, as depicted in low-angle shots depicting her anxious gaze staring up at the windows that bear down on her. THE CHANGELING, discussed in Chapter One, also features a scene in which John walks in his front yard only to have shards of stained glass fall at his feet from the attic window. A tense shot constructs his perspective as he stares up at the window, expecting to see someone watching him. This scene facilitates his exploration of the attic in which the child, Joseph, died. THE OTHERs is strongly influenced by all of these films, and this final scene plays upon the eerie, intertextual realization that we and the three central characters have in fact been on the 'other' side of the window throughout the film. 


\section{Conclusion}

Ultimately THE OTHERS aestheticizes Trigg's characterization of the eerie sensation in which the 'aftermath' of rational history becomes evident to us within the unoccupied, decaying structure, in which:

the emergence of decline becomes the figure which defines time and space. Accordingly, as the content of history loses its privileged certainty, so too does the form. Conjoined with the incongruity between the present stage of things and the remains that linger, an anticipatory waiting emerges. The beginning of history and the end of history converge, the boundaries ambiguous. In the wavering space in between, temporal uncertainty forms. (2006, 194-195)

In its subversion of the traditional ghost story arc, THE OTHERs emphasizes this site of decline, which challenges history's accepted form. The decay of the house that Grace and her children inhabit is imminent, as is the gradual dissolution of their own identities - the house is caught at a point of becoming-unhomely, becoming-ruin, just as Grace and her children are caught at a point of becoming-ghost. The audience identifies not with the 'present' characters who move forwards through historical time, but with the spectral remains of this past that lingers. We are thus locked into an anticipatory waiting between a present that has passed and a future that becomes present, with the diegetic present functioning as an unsettled slip-zone in between. The ambiguity of the historical setting - between the final stages of WWII and the beginning of the postwar period - confounds historical progress by intermingling beginnings and endings in a similar manner. This temporal uncertainty is embodied by the child whose growing up has become her decay, another conflation of beginnings and endings that aestheticizes the eerie encounter with progress stripped of its teleological function. Thus, via its detachment from specific national narratives of history and progress, THE ОтнеRs deploys the uncanny child to work through the liminality of the early 2ooos, as the 2 oth century was displaced by a long-awaited new epoch: a felt transition in which the present became past, inciting an uncanny defamiliarization of all that once was in the face of the future becoming-present. 


\section{Works Cited}

Baudrillard, Jean. The Illusion of the End. Trans. Chris Turner. Stanford: Stanford University Press, 1994. Print.

—.'The Millennium, or the Suspense of the Year 200o.' Trans. Julie Witwer. The Jean Baudrillard Reader. Ed. Steve Redhead. New York: Columbia University Press, 2008. 153-170. Print.

Bauman, Zygmunt. Liquid Life: Living in the Age of Uncertainty. Cambridge: Polity, 2007. Print.

Boym, Svetlana. 'Nostalgia and its Discontents.' The Hedgehog Review 9.2 (2007): 7-18. EBSCO Host Humanities International Complete. Web. 30 Sep. 2014.

Deleuze, Gilles. Cinema 2: The Time Image. 1985. Trans. Hugh Tomlinson and Robert Galeta. Minneapolis: The University of Minnesota Press, 1997a. Print.

—.Negotiations, 1972-199o. Trans. Margin Joughin. New York: Columbia University Press, 1997b. Print.

Diamond, Nicola. 'The Body, Emotion and Cinema: Perspectives on Cinematic Experiences of das Unheimlich and Estranged Body States in THe OтнERs.' Media and the Inner World: Psycho-cultural Approaches to Emotion, Media and Popular Culture. Ed. Caroline Bainbridge and Candida Yates. New York: Palgrave Macmillan, 2014. 82-98. Print.

Edelman, Lee. No Future: Queer Theory and the Death Drive. Durham: Duke University Press, 2004. Print.

Fass, Paula S. Children of a New World: Society, Culture, and Globalization. New York: New York University Press, 2007. Print.

Fraser, J.T. 'An Embarrassment of Proper Times: A Foreword.' Time: The Modern and Postmodern Experience. By Helga Nowotny. Trans. Neville Plaice. Cambridge: Polity Press, 1996. 1-6. Print.

Hammond, Philip. Media, War and Postmodernity. London: Routledge, 2007. Print. Jenks, Chris. Childhood. $2^{\text {nd }}$ Ed. New York: Routledge, 2005. Print.

Lyotard, Jean-François. The Postmodern Condition: A Report on Knowledge. 1979. Trans. Geoff Bennington and Brian Massumi. Minneapolis: University of Minnesota Press, 1983. Print.

Natoli, Joseph. Speeding to the Millennium: Film and Culture, 1993-1995. Albany: State University of New York Press, 1998. Print.

Rüsen, Jörn. Time and History: The Variety of Cultures. New York: Berghahn Books, 2007. Print.

Staal, Rein. 'The Forgotten Story of Postmodernity.' First Things December (2008): 35-39. EBSCOhost Academic Search Complete. Web. 30 Sep. 2014.

Stagoll, Cliff. 'Becoming.' The Deleuze Dictionary Revised Edition. Ed. Adrian Parr. Edinburgh: Edinburgh University Press, 2013. 25-27. Print. 
Swiboda, Marcel. 'Becoming + Music.' The Deleuze Dictionary Revised Edition. Ed. Adrian Parr. Edinburgh: Edinburgh University Press, 2012. 27-29. Print.

Tomlinson, Niles. 'Of Horse Blood and TV Snow: Abhuman Reproduction in THE RING.' The Scary Screen: Media Anxiety in The RING. Ed. Kristen Lacefield. Surrey: Ashgate Publishing, 2010. 175-190. Print.

Trigg, Dylan. The Aesthetics of Decay: Nothingness, Nostalgia, and the Absence of Reason. New York: Peter Lang, 20o6. Print.

-.The Memory of Place: A Phenomenology of the Uncanny. Athens: Ohio University Press, 2012. Print.

Uprichard, Emma. 'Children as "Beings and Becomings": Children, Childhood and Temporality.' Children and Society 22 (2008): 303-313. Wiley Online Library. Web. 30 Sep. 2014.

Vidler, Anthony. The Architectural Uncanny: Essays in the Modern Unhomely. Cambridge: Massachusetts Institute of Technology, 1992. Print.

Zamora, Lois Parkinson. 'Apocalypse.' Dictionary of Literary Themes and Motifs: A-J. Ed. Jean-Charles Seigneuret. Westport: Greenwood Publishing, 1988. 87-96. Print. Zipes, Jack. Relentless Progress: The Reconfiguration of Children's Literature, Fantasy and Storytelling. New York: Routledge, 2009. Print.

\section{Filmography}

The Changeling. Dir. Peter Medak. 1980. HBO Home Video, 2005. DVD.

The Haunting. Dir. Robert Wise. Argyle Enterprises, 1963. Film.

The InNocents. Dir. Jack Clayton. 1961. Criterion Collection Home Entertainment, 2014. Blu-ray DVD.

The Others [Los отros]. Dir. Alejandro Amenábar. 2001. Optimum Home Entertainment, 2011. Blu-ray DVD.

The Ring. Dir. Gore Verbinski. 2002. DreamWorks Pictures, 2013. Blu-ray DVD.

Scary Movie 3. Dir. David Zucker. Dimension Films, 2003. Film.

Spanish Movie. Dir. Javier Ruiz Caldera. Telecino Cinema, 2009. Film.

'Treehouse of Horror XXV.' The Simpsons: Season 26, Episode 4. Dir. Matthew

Faughnan. Gracie Films and $20^{\text {th }}$ Century Fox Television, 2014.

VIRIDIANA. Dir. Luis Buñuel. Unión Industrial Cinematográfica (UNINCI), 1961. Film. Who Are We? [Hum Kaun Hai?]. Dir. Ravi Sharma Shankar. 4U2C Film, 2004. Film. 